\title{
Lay of the Land: The State of Bibliographic Instruction Efforts in ARL Special Collections Libraries
}

\section{Introduction}

MUCH HAS CHANGED IN THE WORLD of special collections and library management since Susan Allen published results of her 1995 survey on the status of special collections at liberal arts colleges. ${ }^{1}$ In 2001, Judith Panitch published results of the Association of Research Libraries (ARL) 1998 survey of special collections, but little data in that report addressed staffing requirements, spaces, and attitudes as related to bibliographic instruction. ${ }^{2}$ In 2004, Anna Allison conducted a thorough survey of some of these issues as well as attitudes toward bibliographic instruction in special collections settings. ${ }^{3}$ Most recently, Berenbak et al. published the results of a 2010 survey of 79 ARL member institutions examining special collections engagement. ${ }^{4}$ Given recent advances in instructional technologies and increased access to digitized materials, as well as the recent economic recession, it is important to re-evaluate the role of bibliographic instruction and special collections in general. A survey in the fall of 2009 elicited detailed information from a wide range of libraries with special collection holdings. The results of the survey and some discussion of the changes since Allen, Panitch, Allison, and Berenbak et al. produced their works appear below. These new data may provide guidance and support for continued use of special collections in collegiate instructional endeavors.

A wide variety of instructional foci and styles exist in special collections settings. This study included all forms of information literacy, course-based instruction, or other collection-specific instruction. The purpose was not to examine the pedagogical facets of instruction in special collections settings, but to provide insight into the facilities, organization, and content that promote effective instruction.

1. Susan M. Allen, "Rare Books and the College Library: Current Practices in Marrying Undergraduates to Special Collections," Rare Books \& Manuscripts Librarianship 13.2 (1999): 110-19.

2. Judith M. Panitch, Special Collections in ARL Libraries (Washington, D.C.: Association of Research Libraries, 2001).

3. Anna E. Allison, "Connecting Undergraduate with Primary Sources: A Study of Undergraduate Instruction in Archives, Manuscripts, and Special Collections" (MSLS thesis, UNC Chapel Hill, 2005).

4. Berenbak et al., Special Collections Engagement (Washington, D.C.: Association of Research Libraries, 2010). 
Furthermore, the study looked briefly at attitudes and roles of outreach in special collections as they relate to instruction. In this context, the study broadly defined outreach as "activities provided by special collections and archives that foster use of materials and resources to enhance both education and research." aspect of special collections activities lies at the heart of the promotion of the use of special collections holdings and is the key to fostering collegial relationships with both researchers and faculty.

\section{Literature Review}

Library literature is clear on the value of bibliographic instruction in libraries in general and, in the last 30 or so years, in special collections settings. However, many special collections-related writings such as Greene, Reichel and Ramey, and Reynolds and Sauter have focused on assignment-specific case studies in individual libraries. A decade ago, Schmeissing and Hollis described a "noticeable dearth in the existing scholarly discourse regarding bibliographic instruction or course-integrated instruction in rare books and special collections librarianship." The completion of several recent comprehensive surveys by Panitch, Allison, and Barenback et al. has helped fill the gap. This 2009 survey continues that trend by complementing Berenbak et al.'s focus on instruction in a broad sense and how it interplays with special collections outreach as a whole with a specific concentration on clarifying the roles of staffing, funding, spaces, and the types of materials that allow such instruction to occur in the many sizes and forms of special collections in North American ARL member institutions.

Michelle McCoy's 2010 article, “The Manuscript as Question,” is a good starting point for establishing the value of special collections to college students and their usefulness in educational assessment. ${ }^{6}$ McCoy finds undergraduate instruction and use "fruitful on multiple levels," especially when combined with the forging of strong faculty and librarian relationships. Furthermore, the value of teaching from archives allows for transformation of "the traditional pedagogical model in which the teacher owns and disseminates information the students lack," to one that Bianca Falbo terms a more "student-centered classroom."

Panitch's 2001 report, which posts general data on lectures, presentations, and tours but does not indicate how special collections departments conduct teaching, touches lightly on the importance of instruction. ${ }^{8}$ Panitch does note that 89 out of

5. Berenbak et al., Special Collections Engagement, 11.

6. Michelle McCoy, "The Manuscript as Question: Teaching Primary Sources in the Archives: The China Missions Project," College \& Research Libraries 71.1 (Jan. 2010): 60.

7. Bianca Falbo, "Teaching from the Archives," RBM: A Journal of Rare Books, Manuscripts, and Cultural Heritage 1.1 (2000): 33.

8. Panitch, Special Collections, 102. 
the 99 institutions she surveyed indicated they taught classes ranging in size from 0 to 250 each year and interacted with drop-in visitors. But there is not much additional data on which library staff members were conducting these classes, where they were held, or how they were supported in terms of materials. Instead, the report more fully investigates other collection-based activities such as digitization, development, publications, and exhibits.

Similarly, Allen notes that, in 1995, as many as one-third of the liberal arts colleges surveyed did not have a professional librarian dedicated to special collection departments, an obvious hindrance to professional instruction on the identification, use, and interpretation of special collections materials. ${ }^{9}$ This understaffing level is rather acute compared to the findings of the 1998 ARL survey by Panitch, as those data, gathered from a wider pool of college sizes, indicated that all of the academic libraries surveyed had a professional special collections librarian, though at least one institution reported only having a half-time professional staff member in that position. ${ }^{10}$ Staffing levels were also reflected in the 2004 Allison survey, which reported a mean full-time professional staffing level of 5.06 and a minimum of $0.75 .{ }^{11}$

In their 2010 study, Berenbak et al. touched upon instruction as part of their survey, but mainly as it relates to overall engagement of special collections with outside entities. They included questions on staffing devoted to "curricular engagement," access to "collaborative spaces," and typical class sizes for a "typical instruction class." However, they did not address specific types of facilities, staffing levels dedicated to instruction, and available technologies to support instructional efforts.

\section{The Survey Instrument and the Call for Participants}

To obtain a higher level of detail from a pool of the ARL respondents, this new survey instrument consisted of 44 questions. Parts of the question set, such as the demographics section, resembled questions found in the 1998 Special Collections in ARL Libraries survey sponsored by the ARL Research Collections Committee and others from the Allison survey instrument. Colleagues from the Special Collections division of the Joyner Library at East Carolina University helped craft and revise the remainder. The varying question styles featured numeric ranges for demographic inquiries, Likert Scale questions to gauge respondent impressions of a topic, and free-form queries to allow respondents to enter answers in their own terms.

The author administered the survey via SurveyMonkey from September through

\footnotetext{
9. Allen, "Rare Books and the College Library," 112.

10. Panitch, Special Collections, 86 .

11. Allison, "Connecting Undergraduates with Primary Sources," 26.
} 
November 2009. ${ }^{12}$ Potential respondents received e-mail requests and reminders to complete the survey. The e-mails explained the purpose of the survey and the manner in which the resultant data would be analyzed and provided contact information for the survey administrator. There were five sections in the survey:

- Demographic Information

- Bibliographic Instruction (Organization)

- Bibliographic Instruction (Sessions and Content)

- Instructional Spaces

- Bibliographic Instruction (Attitudes)

The pool of potential respondents consisted of librarians, curators, and directors working in the ARL member special collections libraries directory maintained by the University of Virginia's Rare Book School. ${ }^{13}$ To avoid duplication, in cases where institutions had more than one library listed in the directory, the survey went only to the main library's special collections unit. Respondents were asked to compile statistics for their responses if their special collections were spread across more than one administrative unit, even though this may have led reported data to be drawn from disparate collections. The response rate was $45(25 \%)$ of the 176 libraries contacted, and 36 of those were usable for the purposes of this study. Despite this low usable response rate of $20.4 \%$, the data and comments in the completed responses remain valuable.

\section{Demographic Profile of the Respondents}

\section{Institution and Home Library}

Most of the respondents worked at public institutions (63.9\%), while 9.5 percent self-identified with private colleges. The remainder identified as Provincial/Canadian or Private but with partial public funding (11.1\%). All but one institution granted doctoral degrees, and the exception offered masters-level and/or professional degrees. The number of full-time students at the participating institutions averaged 23,640 for undergraduates and 6,642 for graduate students. However, these numbers varied widely, from 4,000 to 60,000 undergraduates and 650 to 15,000 graduate students. The general collection sizes of the respondents' institutions were fairly large, with most $(86.1 \%)$ saying that their home library contained more than 2,000,000 volumes. Though the remaining institutions held fewer total volumes, only one reported having fewer than 100,000.

12. Survey Monkey is an online survey construction and administration tool available at www.surveymonkey.com [accessed 29 February 2012].

13. University of Virginia's Rare Book School is available online at www.rarebookschool.org/directories/ [accessed 29 February 2012]. 


\section{Size of the Special Collections}

All of the respondents reported maintaining manuscripts and rare book collections. A majority also reported holdings of university archives, map collections and electronic records. When asked to specify any other holdings, respondents referred to visual images, audio recordings, architectural drawings, theses, sheet music, film, and artifacts.

The size of the special collections varied from 9,000 to 800,000 volumes, 100 to 70,000 linear feet of manuscripts, and 1,000 to 26,000 linear feet of university archival materials. Some respondents specified the size of other groups of materials, which included approximately 2,000,000 photographs at one library, more than 40,000 microforms at another, and 200,000 items of ephemera at a third. These numbers represent a wide range of collection sizes and types of holdings.

\section{Departmental Funding}

Only half of the respondents reported endowments for their special collections, and few of them stated the value of the endowments. These sums ranged from a low of $\$ 247,000$ to a high of $\$ 28,000,000$. Of the 31 respondents who provided an approximate number for their annual acquisitions budget, there was an average of $\$ 190,000$, with a range of $\$ 10,000$ to $\$ 1,000,000$. Only three collections reported an acquisitions budget over $\$ 500,000$, with most spending closer to $\$ 100,000$ annually. These answers illustrate a wide range of funding for the respondents, and it can be inferred from the lower end that perhaps not all of the institutions would have the ability to devote large amounts toward acquisitions that would support purchases that come up for sale on short notice or would support emergent research topics .

\section{Staffing \& Facilities}

Survey questions on the average number of employees in each collection broke into categories of job titles and rank. The mean number of librarians in each collection was 5.17, with 3.93 people in other professional staff roles, 7.71 support staff, 2.89 graduate assistants, and 9.19 undergraduate workers. However, these averages disguise wide variations. The actual reported number of librarians ranged from one to sixteen, while the number of support staff ranged from one to fifty, and some institutions did not use student workers.

A minority of respondents (38.9\%) reported that their librarian or archivist positions were tenure-track. Of those who responded positively, only 10 percent reported a requirement for these employees to engage in teaching other than bibliographic instruction. 
On questions about the number of staff service points, five respondents declared three points (and one institution had four), but the majority (24 out of 36) of these collections offered only one service point. The collections averaged 39.97 hours of service each week, with only four offering fewer than 30 hours and another four more than 50 hours per week.

When asked if departments have staff members whose primary responsibility is outreach, only 21.6 percent responded in the affirmative. Of those who did respond positively, nine collections had one outreach employee and two collections reported two. An even smaller number of collections (19.4\%) reported having staff members whose primary responsibility was providing bibliographic instruction. Of those, one collection had a half-time position dedicated to instruction, while seven others maintained one instructor.

\section{Bibliographic Instruction (Organization)}

One question in the survey asked who leads bibliographic instruction sessions in each collection. Not surprisingly, we learned that librarians or archivists led the bulk $(97.2 \%)$ of the sessions. Other staff serving as instructors included support staff from within special collections (38.8\%), librarians from outside the department $(16.6 \%)$, and graduate students $(8 \%)$. One institution reported that faculty members from an academic department led sessions, and one noted that main library personnel handled all their bibliographic instruction.

\section{Bibliographic Instruction (Sessions and Content) Instruction and Campus Relations}

In all, 69.4 percent of respondents said their department took part in a new faculty orientation program or similar event to make teaching faculty aware of their holdings and services. However, only 66.4 percent said their department maintained a Web page that explained to interested faculty or groups how to contact the instruction coordinator or schedule a bibliographic instruction.

A substantial majority (72.2\%) of respondents indicated they had standing bibliographic instruction sessions with particular faculty or departments every semester or academic year. Most of these relationships have existed for more than five years (for 24 of 26 who responded to this free-form question); eight collections reported connections of 20 years or more with a particular department or instructor. This suggests that, when relationships are developed between academic departments and special collections, they tend to last. The top three disciplines supported by respondents' bibliographic instruction sessions were History (including Medieval Studies, History of Science, and History of Medicine), English and Literature, and Art and 
Design (including Art History). The Allison survey produced similar results, listing the most requests as coming from History, English, and Art or Art History. ${ }^{14}$

A large percentage of respondents $(86.1 \%)$ noted a growing number of requests for bibliographic instruction sessions in the last five years. However, only 25 percent indicated they assess the impact of their department's efforts. This suggests a mismatch between the need for service and assessment or reflection on the quality of service provided. Asked to describe the type of assessment conducted, respondents split between gaining feedback from students or their academic instructors. Most feedback came through written evaluations or informal conversations.

Only two libraries reported that the recent economic downturn had affected the nature or number of departmental bibliographic instruction sessions. In both cases, the downturn had led to staffing reductions or concerns, and these resulted in a reduced number of instructional sessions.

\section{Instruction Sessions}

All respondents indicated they offered bibliographic instruction sessions to scheduled groups of multiple students or patrons, while more than 86.1 percent also offered scheduled and drop-in one-on-one research consultations. Only 38.8 percent reported they conducted unscheduled visits with groups of patrons or students and very few respondents (3 out of 36) indicated they offered some form of asynchronous online tutorials or instruction.

Regarding scheduled in-person group sessions for faculty or students, only 13.8 percent of respondents indicated they conducted fewer than ten such sessions each year. An additional 27.7 percent indicated they gave 60 or more instruction sessions per year, 33.3 percent gave 10-29 such sessions annually, and 25 percent gave 30-59 such sessions. These numbers contrast significantly with the number of respondents who offer scheduled instruction sessions to groups from outside the institution, where the majority (63.8\%) offer 9 or fewer of these sessions annually.

A follow-up question asked for information on the types of patrons served in these sessions. The highest numbers were for upper-level undergraduates, followed by graduate students, freshman-level undergraduates (introductory freshman writing and research), faculty, and groups from outside the institution.

The average length of a scheduled bibliographic instruction session was 30-60 minutes $(69.4 \%$ of respondents), with only one indicating they held sessions less

14. Allison, "Connecting Undergraduates with Primary Sources," 30. 
than 30 minutes in length, and nine reporting sessions longer than one hour. Slightly more than half $(55.5 \%)$ of respondents conducted scheduled sessions for an average of fewer than 20 students, with just under half (44.5\%) providing them for 20-29 students. No respondents indicated they gave scheduled sessions to more than 29 students or patrons in their sessions. The last result is somewhat intriguing, as it may indicate that many special collections are not engaging in instructional activities with lower-level undergraduate courses, which tend to be larger in size. This is in contrast to Berenbak et al., who reported that some institutions provided instruction to classes as large as 75 students. ${ }^{15}$

The types of materials used to support bibliographic instruction included actual special collections holdings (noted by $100 \%$ of surveyed), digitized materials $(72.2 \%)$, and facsimiles of special collections holdings (47.2\%). One respondent indicated they also made use of video materials during instruction sessions.

Of respondents who indicated they were involved in library or campuswide digitization efforts, 81.2 percent used digitized materials to support their instruction sessions. These materials functioned as digital surrogates, to facilitate preservation of rare or fragile materials and to allow for demonstration of online finding aids, repositories, and effective searching techniques.

\section{Instructional Spaces}

The type of instructional space available to departments included, in descending order, existing spaces inside special collections such as reading/research rooms, classroom space dedicated to the department, classrooms shared with another department, and classrooms outside the library visited by special collections members. Within primary instructional spaces, 10 of the 36 respondents said seating was available for fewer than 20 patrons, while 14 others indicated their rooms had 20-29 seats. The remainder of respondents provided instruction in rooms with seating for 30 or more people.

Technologies available in primary instructional spaces were typically projection equipment $(88.2 \%)$, desk or laptop computers for student/patron use (41.2\%), SMART podiums (20.6\%), and digital document readers (14.7\%). Additionally, respondents mentioned such other old and new technologies such as a Hinman Collator and audio playback equipment.

\section{Bibliographic Instruction (Attitudes)}

In characterizing the biggest challenges to providing instruction, respondents most commonly cited uneven faculty interest, staffing levels, and communicating the scope

15. Berenbak et al., Special Collections Engagement, 11. 
of the holdings to faculty members. Respondents overwhelmingly (77.7\%) felt their departments needed to focus more on faculty outreach to generate more bibliographic instruction sessions. One respondent particularly reported their department had difficulty forming instructional relationships with graduate programs at their institution.

However, this apparent need for better communication is less obvious when viewing the responses in regard to their level of agreement with the following statement: "My institution's faculty are aware of the types of resources our collection has and services that it offers."

Here respondents were evenly divided in their opinions. Thirteen "agreed" or "strongly agreed" with the statement, while thirteen "disagreed," and another eleven respondents "neither agreed nor disagreed." This seems to imply a significant disparity between those respondents who held the opinion that faculty outreach is a challenge versus those who perceive their institution has done an effective job at marketing the holdings and services within their collections to faculty.

The least commonly reported concerns were with the availability of digitized materials to support instruction, the quality of classroom instructional technology, and budget issues. These responses were further supported by the large percentage of respondents $(72.2 \%)$ who felt that their instruction efforts adequately prepared their students for working with special collections resources.

\section{Discussion}

Overall, it appears that the state of bibliographic instruction in special collections libraries is healthy and expanding, with respondents reporting a general increase in requests for instruction and growing relationships with faculty. Some issues, however, remain for administrative and instructional attention.

Instruction is assuming a bigger role for special collections departments, with 97.4 percent offering bibliographic instruction sessions. In contrast, Allen had previously noted only $83.34 \%$ of institutions offering classes, also noting that this service ranked behind drop-in visits, tours, and exhibitions. ${ }^{16}$ Thus, the instructional focus of special collections seems to have increased. Additionally, Allen's survey indicated that 30 percent of the special collections surveyed in 1995 did not have a full-time librarian professional, while the 2001 Panitch report found all 99 of the ARL institutions had at least one special collections librarian. ${ }^{17}$ In this survey, every special collection had at least one professional librarian, with the average at 4.92 FTE. One could infer from this that the respondents have the ability to take on signifi-

16. Allen, "Rare Books and the College Library," 112.

17. Panitch, Special Collections, 86. 
cant numbers of bibliographic instruction sessions. In hours of service, half of the liberal arts colleges Allen surveyed provided 40 or more hours of service per week while, for the ARL member institutions in this survey, that number rose to twothirds of all respondents. ${ }^{18}$

This survey repeated the findings of others, as it identified the disciplines of History, English, and the Visual Arts as the top three academic fields for special collections use. The absence of Education, Physical Sciences, Mathematics, Business, or Engineering in any of the top three responses is not surprising when considering a department of a local or regional history-based special collection, but it may reflect a gap between special collections foci and research needs on many American campuses. A large part of this relates to the actual holdings in any given special collection department, but the results also suggest that librarians need to think creatively about marketing their collections more widely to teaching faculty. In particular, collections with a regional focus could encourage instructors to develop local casestudy assignments for their students.

Staffing pressures and levels of faculty interest emerged as the top two issues from responses relating to challenges and concerns. This points to a potential dilemma for librarians who wish to see greater use of their services and resources, including instructional sessions, but who realize that such an increase will likely result in a need for additional staff to meet these goals.

There are several ways to address the concern about faculty interest in, and knowledge of, special collections holdings and services. In 1999, Allen noted the need for both special collections and "regular" librarians to maintain lines of communication, and she hoped the latter would "plug" special collections holdings or service while they were providing bibliographic instruction in the home libraries. ${ }^{19}$ This survey reinforces that point, and it seems particularly relevant for those few departments that leave special collections bibliographic instruction to home library staff.

Respondents emphasized this need for better communication in both the objective and open-ended questions on developing and maintaining ties with faculty. This supports Allen's call for efforts to "charm faculty into collaborative efforts," since professors who participate once in course-based special collections instruction, or who conduct their own special collections research, are more likely to return with their students. ${ }^{20}$ Given the number of respondents who said they attend new faculty orientation or similar events (69.4\%), it seems many institutions are on the right

\footnotetext{
18. Allen, "Rare Books and the College Library," 113.

19. Ibid.

20. Allen, "Rare Books and the College Library," 115.
} 
track for opening this line of communication. In contrast, it seems that a simple, quick outreach mechanism is being overlooked by the approximately 33.6 percent of institutions that fail to post information on contacting a special collections instruction coordinator or for scheduling instruction sessions on their own Web sites.

Also in this survey, the majority of respondents indicated that they conducted no assessment of their instructional efforts. This finding mirrors the results of the Berenbak et al. study, which reported that many institutions were not formally evaluating student use of materials in research projects. ${ }^{21}$ Given the national push for assessment, whether associated with accreditation activities or proving worth in times of fiscal crisis, it seems that a deeper focus on gathering evaluative data is warranted. This also indicates the importance of early integration of assessment into instructional and outreach efforts.

The high reported use of digitized materials to support instruction by respondents involved in campuswide digitization efforts (81.2\%) suggests that special collections are embracing technological advances. As library technology advances, this will have an increasing impact on the nature and content of special collections instruction. Students will be able to access the content of rare and fragile materials at their point of need, free of such traditional constraints as limited service hours and secure reading environments. There will also be less competition for high-demand materials, since multiple researchers will be able to see them simultaneously. This will allow several students, or even an entire class, to focus on a set of materials as a group, without feeling the need to "queue-up" for access. The last should be particularly attractive to classroom instructors who can now ask their special collections counterparts to set up "digital dossiers" of materials for specific assignments.

Further, the capacity to download digital surrogates will let students "take ownership" of materials that previously had to remain static for preservation and security purposes by making changes to the electronic version if they like. Should they make too many changes, in effect destroying the digital surrogate or changing it to the point that it loses value, they can simply download a fresh copy and begin again.

In addition, the increasing use of digitized materials will allow special collections librarians and instructors to take their instruction "on the road." Students will no longer need to come to special collections or even the library to receive instruction. Instructors can now interact with and teach the students in their usual classroom, decreasing the anxiety many students feel when they first come to the physical collection with its intimidating rules and regulations. The wonder of seeing and interacting with rare materials will no longer exist solely in a specific location.

21. Berenbak et al., Special Collections Engagement, 78-80. 
That being said, a recent article by Anne Bahde described an off-site session that exposed a large undergraduate journalism class to the select holdings from a collection of vintage newspapers and how the class benefitted from interacting with the physical objects rather than their digital surrogates. She notes that the students were able "to draw sensible and thoughtful conclusions on topics currently at issue in their field and in their world, such as media durability and permanence, reliability and authenticity of information, readability of content and layout, and usability." ${ }^{22}$ The possibility of taking the physical holdings outside of special collections is an intriguing one, though potentially problematic due to the necessary precautions that must be taken to ensure the security and safety of the materials during transport and viewing in a less controlled environment as was documented in the article.

The ability to move instruction out of a traditional library setting can also decrease the competition for instructional spaces within the library itself, especially for special collections units that share instructional spaces with traditional reference and orientation departments. This will allow for greater flexibility when scheduling instruction sessions and may encourage more classroom instructors to look to special collections for academic support. There are also expanded possibilities of reaching distance education students, a growing area of service that should provide opportunities to expand the impact of special collections outside the library.

Also of note was the frequent mention of a new pedagogical trend that encourages and even requires student interpretation and inclusion of primary sources in both undergraduate and $\mathrm{K}-12$ course projects. One respondent particularly mentioned the growing relationship between the special collections department staff, $\mathrm{K}-12$ instructors, and students working with National History Day or similar educational projects frequently associated with special collections materials. This type of content-based learning will likely require continued innovation on the part of special collections. Jenny Robb's description of the Opper Project, which encouraged K-12 use of digitized editorial cartoons available online as collaboration among education departments, libraries, and other educators, is one excellent example. ${ }^{23}$ While this collaboration is noteworthy, it also brings to mind the observation of Doris Malkmus, who noted that this coming generation of college students will be "more prepared to deal with primary source documents than any previous generation, but they have not yet developed the skills to find and identify primary sources-whether online or in an archive." ${ }^{24}$ It seems likely that effective bibliographic instruction

22. Anne Bahde, "Taking the Show on the Road: Special Collections Instruction in the Campus Classroom," RBM: A Journal of Rare Books, Manuscripts, and Cultural Heritage 12.2 (2011): 86.

23. Jenny E. Robb, "The Opper Project: Collaborating with Educators to Promote the Use of Editorial Cartoons in the Social Studies Classroom," RBM: A Journal of Rare Books, Manuscripts, and Cultural Heritage 10.2 (2009): 70-94.

24. Doris J. Malkmus, "Primary Source Research and the Undergraduate: A Transforming Landscape," Journal of Archival Organization 6.1-2 (2008): 47-70. 
will help students learn how to locate materials on any topic, through a contextbased examination of the holdings within a particular special collection.

Finally, the relatively small number of academic institutions (38.5\%) in which librarians hold faculty status is interesting. This seems low, considering that ARL membership institutions are prestigious research libraries, and perhaps it indicates a continuing gap between libraries and teaching departments in the area of scholarly research and publishing. For all faculty members, participating in the tenure process encourages innovation and a thoughtful analysis of the research process. This seems to be absent, at least in the results of this study, from many of the surveyed institutions. Additionally, a lack of tenure status may also suggest a reason that many academic faculty members are not more involved in bringing students into the libraries for instruction: they may see librarians as information providers rather than teaching professionals. On the other hand, some colleges and universities that grant tenure to librarians do require teaching outside of bibliographic instruction, as 9 percent of our respondents reported.

Faculty status for librarians has been controversial from its introduction. Its impact on how we function as professionals and how our academic colleagues see us is an ongoing source of debate. ${ }^{25}$ The public discussion between Michael Gorman and Mark Herring, published in American Libraries in 2003, is a typical example. Asked their opinion on whether teaching faculty regarded tenured librarians as peers, their responses contrasted sharply. Gorman cited a positive impact and perception, while Herring stated that it merely provided a "veneer of equality." ${ }^{\text {26 }}$ We need a fuller discussion not only of what it means for librarians to have tenure, but how such ranking will interplay with outreach and instructional efforts in special collections.

\section{Conclusion and Areas for Future Research}

All indications suggest that, though the state of bibliographic instruction in special collections is strong, there is room for improvement. Adequate staffing, properly sized and equipped instructional spaces, and effective communication with faculty are all areas in need of attention. Librarians seem keenly aware of these shortcomings, which is the first step toward addressing these issues and firmly cementing the role of special collections in the modern academic curriculum. There are also some

25. Mark Y. Herring and Michael Gorman, "Conference Call: Do Librarians with Tenure Get More Respect?” American Libraries 34.6 (June-July 2003); Jeanie M. Welch and Frada L. Mozenter, "Loosening the Ties That Bind: Academic Librarians and Tenure," College and Research Libraries 67.2 (2006); Alan Bernstein, "Academic Librarians and Faculty Status: Mountain, Molehill or Mesa," Georgia Library Quarterly 46.2 (2009); Shalu Gillum, "The True Benefit of Faculty Status for Academic Reference Librarians," The Reference Librarian 51.4 (2010); Steve McKinzie, "590: Local Notes-Tenure for Academic Librarians: Why it Has to Go," Against the Grain 22.4 (2010).

26. Mark Y. Herring and Michael Gorman, "Conference Call: Do Librarians with Tenure Get More Respect?” 72 . 
things that we seem to be doing quite well, such as the integration of digitized holdings into instruction, making digitized copies available to researchers at their time and point of need.

There are several avenues for future research. Perhaps the most important of these is expanding the respondent pool for future surveys. Most special collections surveys, including this one, aim at ARL member libraries. To gain fuller insights, we should expand our reach to include nonmembers, who can provide relevant new information of their own and for contrast against the ARL data. Researchers may also wish to survey special collections based on collection type, to account for differences that stem from the diverse materials and organization that can impact instruction and outreach efforts and goals.

Additionally, there is room for study of the impact of technological advances in special collections and the way that they engage students in instructional environments. Researchers should consider a wide array of impacts beyond mere digitization, including such possibilities as distance education, course-integrated instruction via Blackboard and other course-management systems, and interactions of students and faculty with special collections holdings in an online environment.

\section{CALADEX}

LOGISTICS

PERSONALISED TRANSPORTATION MANAGEMENT specializing in fine book packing and shipping On-site packing by our qualified team Door to door transportation from any USA point
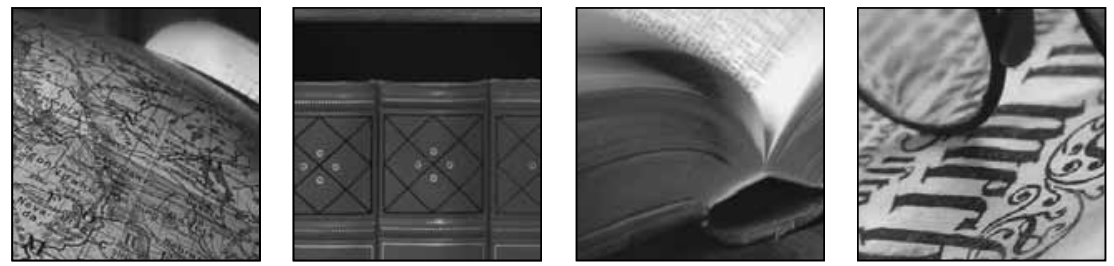

For information on Caladex LLC and the services we offer, please contact us at:

USA \& CANADA

Tel:

Fax:
8006434315

7182334159
UK

Tel:

Fax:
02079938511

02076813435

Email: info@caladex.com • www.caladex.com 